\title{
Dihydroxyacetone: a Product of Xylulose 5-Phosphate-dependent Fixation of Formaldehyde by Methanol-grown Candida boidinii
}

\author{
By M. J. WAITES AND J. R. QUAYLE* \\ Department of Microbiology, The University, Sheffield S10 2TN
}

(Received 10 December 1979)

\begin{abstract}
The reaction between xylulose 5-phosphate and formaldehyde catalysed by cell-free extracts of methanol-grown Candida boidinii has been examined. Dihydroxyacetone was identified as a reaction product by thin-layer chromatography. The dihydroxyacetone was labelled when $\left[{ }^{14} \mathrm{C}\right]$ formaldehyde was used as substrate. Xylulose 5-phosphate was a better substrate than ribulose 5-phosphate or ribose 5-phosphate. Little activity was observed in extracts of glucose-grown $C$. boidinii. It is proposed that the enzyme responsible is the dihydroxyacetone synthase previously postulated as a key enzyme in assimilation of methanol by yeasts. For the detection and accurate assay of this enzyme it is essential first to remove methanol from cell-free extracts of the organism.
\end{abstract}

\section{INTRODUCTION}

Recent studies (van Dijken et al., 1978; Babel \& Loffhagen, 1979; O'Connor \& Quayle, 1979) have suggested that a novel pentose phosphate cycle of formaldehyde fixation operates in methanol-utilizing yeasts. This metabolic scheme, called the dihydroxyacetone (DHA) pathway, involves three key enzymes: triokinase, fructose 1,6-bisphosphatase and a postulated formaldehyde-condensing enzyme leading to the formation of DHA from formaldehyde plus pentose phosphate. The above studies provided enzymological and mutant evidence in support of the involvement of the first two of these enzymes in the assimilation of methanol by yeasts. It was suggested that the third enzyme may be a transketolase catalysing the transfer of a glycolaldehyde fragment from xylulose 5-phosphate to formaldehyde as acceptor, leading to formation of glyceraldehyde 3-phosphate and DHA. Such a reaction would be similar to that discovered by Dickens \& Williamson (1958) in which transketolase from Saccharomyces cerevisiae catalysed the transfer of a glycolaldehyde fragment from hydroxypyruvate to formaldehyde, liberating carbon dioxide and forming DHA.

The present paper describes the identification of DHA as a product of the reaction between formaldehyde and xylulose 5-phosphate catalysed by cell-free extracts of methanolgrown Candida boidinii. While this work was in progress a report describing a similar enzyme system in methanol-grown Kloeckera sp. 2201 was published by Kato et al. (1979).

\section{METHODS}

Abbreviations. DHA, dihydroxyacetone; DHAP, dihydroxyacetone phosphate; GAP, glyceraldehyde 3-phosphate; TPP, thiamin pyrophosphate; XuMP, xylulose 5-phosphate.

Organism and growth. Candida boidinii CBS 5777 was grown in shake flasks at $30^{\circ} \mathrm{C}$ in the mineral salts medium used by van Dijken et al. (1976). Filter-sterilized methanol $(0 \cdot 5 \%, \mathrm{w} / \mathrm{v})$ or autoclaved glucose $(0 \cdot 2 \%, \mathrm{w} / \mathrm{v})$ were used as carbon and energy sources. For all enzyme studies, cultures were harvested in late-exponential phase by centrifugation at $6000 \mathrm{~g}$ for $20 \mathrm{~min}$. Cell paste was either used directly or resuspended in 50 vol. 20 mM- $\mathrm{KH}_{2} \mathrm{PO}_{4} / \mathrm{NaOH}$ buffer $\mathrm{pH} 7 \cdot 1$ for $1 \mathrm{~h}$ at room temperature and then collected by recentrifugation. 
Preparation of extracts. Cell-free extracts of $C$. boidinii were always prepared from fresh cell paste (washed or unwashed) by ultrasonication (MSE model $150 \mathrm{~W}$ ) at $0^{\circ} \mathrm{C}$ for $6 \times 1 \mathrm{~min}$ in 4 vol. $20 \mathrm{mM}-\mathrm{KH}_{2} \mathrm{PO}_{4} / \mathrm{NaOH}$ buffer $\mathrm{pH} \mathrm{7 \cdot 1.} \mathrm{Preparations} \mathrm{were} \mathrm{centrifuged} \mathrm{at} 38000 \mathrm{~g}$ for $20 \mathrm{~min}$ at $4{ }^{\circ} \mathrm{C}$ and the supernatants were used as the cell-free extract. Where necessary, $2 \mathrm{ml}$ samples were applied to a Sephadex G-25 column $(1 \times 6 \mathrm{~cm})$ equilibrated with $20 \mathrm{~mm}-\mathrm{KH}_{2} \mathrm{PO}_{4} / \mathrm{NaOH}$ buffer $\mathrm{pH} 7 \cdot 1$ and the protein was eluted with the same buffer.

Enzyme assay. Assays were carried out at $30^{\circ} \mathrm{C}$. XuMP-dependent formaldehyde fixation activity (DHA synthase) was assayed by determination, with the Nash reagent (Nash, 1953), of the rate of disappearance of formaldehyde in a $1 \mathrm{ml}$ system containing: glycylglycine buffer $\mathrm{pH} 7.6,50 \mathrm{mM} ; \mathrm{MgCl}_{2}, 2 \mathrm{mM}$; TPP, $0.005 \%$ (w/v); glycerokinase (from Candida mycoderma), 2 units; ATP, 1 mм; XuMP, 2.5 mM; and formaldehyde, $1 \mathrm{~mm}$. Assays were started by the addition of the enzyme preparation and $200 \mu 1$ samples of the assay mixture were removed at intervals, added to $800 \mu 110 \%(\mathrm{w} / \mathrm{v})$ trichloroacetic acid and centrifuged at $500 \mathrm{~g}$ for $10 \mathrm{~min}$. Supernatants were then used in the Nash test to determine formaldehyde.

Protein was determined by the Lowry method with bovine serum albumin as standard.

Detection of DHA as a reaction product. (1) Use of thin-layer chromatography (t.l.c.) and a spray reagent. Reactions occurring in $5 \mathrm{ml}$ assay mixture which lacked glycerokinase and ATP were terminated after a $15 \mathrm{~min}$ incubation by the addition of $10 \mathrm{ml}$ acetone with shaking. The mixtures were centrifuged at $500 \mathrm{~g}$ for $5 \mathrm{~min}$, supernatants were decanted, and then evaporated to dryness under reduced pressure at $35^{\circ} \mathrm{C}$. Resultant residues were taken up in $100 \mu \mathrm{l}$ acetone and submitted to one-dimensional t.l.c. Assay products were visualized by spraying with aniline phosphate (Dickens \& Williamson, 1958) and heating at $100^{\circ} \mathrm{C}$ for 5 to $10 \mathrm{~min}$. The spray reagent was prepared by mixing equal volumes of $0.1 \mathrm{M}$-aniline and $0.1 \mathrm{M}$ orthophosphoric acid, which were both made up in water saturated with butan-1-ol.

(2) Incorporation of $\left[{ }^{14} \mathrm{C}\right]$ formaldehyde. Reactions occurring in $1 \mathrm{ml}$ assay mixture lacking glycerokinase and ATP, with crude cell-free extract as enzyme source, and containing $\left[{ }^{14} \mathrm{C}\right]$ formaldehyde, were terminated after $15 \mathrm{~min}$ incubation by the addition of $2 \mathrm{ml}$ acetone and centrifuged at $500 \mathrm{~g}$ for $5 \mathrm{~min}$. Supernatants were decanted and to each supernatant $50 \mu \mathrm{g}$ authentic DHA was added prior to preparation for t.l.c. as described above. Two-dimensional t.l.c. on cellulose was then carried out (see Fig. 1). Air-dried plates were then inverted on to X-ray film (Kodak-Kodirex KD5T) and exposed for 2 weeks. Carrier DHA was then detected by spraying with aniline phosphate.

Quantitative determination of $D H A$ production. Reactions occurring in $1 \mathrm{ml}$ assay mixture lacking glycerokinase and ATP were terminated after $5 \mathrm{~min}$ and prepared for t.l.c. as described above. Preparations were spotted on to silica gel 60 (Merck) plates and chromatographed one-dimensionally using solvent system A or C (each giving an $R_{F}$ for DHA of 0.62 ). The alternative use of cellulose plates was found to interfere with the colorimetric assay of DHA. The area of gel at the $R_{F}$ of authentic DHA was carefully removed and mixed with $2.5 \mathrm{ml}$ distilled water. Mixtures were centrifuged at $500 \mathrm{~g}$ for $5 \mathrm{~min}$ and two $1 \mathrm{ml}$ samples of supernatant were transferred to graduated test tubes. To each, an equal volume of phosphate/molybdate solution was added, which was prepared by the method of Campbell (1926), with phosphomolybdic acid replacing molybdic acid. The tube contents were vigorously mixed and then the tubes were placed in a boiling water bath for $15 \mathrm{~min}$, cooled and made up to $2.0 \mathrm{ml}$ with distilled water. Absorbances at $700 \mathrm{~nm}$ were compared with a calibration curve obtained from known quantities of authentic DHA (1 to $25 \mu \mathrm{g}$ ) which had been taken through the same procedure.

Solvent systems used for t.l.c. The following solvent systems were used throughout: A, ethyl methyl ketone/ acetic acid/boric acid $(4 \%, \mathrm{w} / \mathrm{v})(9: 1: 1$, by vol. $) ; \mathrm{B}$, butan-1-ol/acetone/water $(4: 5: 1$, by vol. $)$, C, phenol/ water $(4: 1, \mathrm{w} / \mathrm{v}) ; \mathrm{D}$, phenol/acetone/butan-1-ol/water $(7 \cdot 4: 4: 3: 1$, by vol.).

Chemicals. Biochemicals and enzymes were obtained from Boehringer, except DHA and XuMP which were purchased from $\mathrm{BDH}$ and Sigma, respectively. Formaldehyde was prepared by heating an aqueous suspension of paraformaldehyde, radioactively labelled or unlabelled, in a sealed ampoule at $110^{\circ} \mathrm{C}$ for 16 to $24 \mathrm{~h}$.

\section{RESULTS}

The detection and assay of the postulated reaction:

$$
\mathrm{XuMP}+\text { Formaldehyde } \rightarrow \mathrm{DHA}+\mathrm{GAP}
$$

in crude extracts of methanol-grown yeasts can be approached by following either the XuMP-dependent disappearance of formaldehyde or by monitoring the formaldehyde- and XuMP-dependent formation of GAP or DHA. Owing to interfering reactions the latter technique presented many difficulties with crude cell-free extracts. The work described in the present paper was based on the XuMP-dependent disappearance of formaldehyde, using the Nash reagent to monitor changes in formaldehyde concentration. At the same 
Table 1. Fixation and formation of formaldehyde catalysed by cell-free extracts of C. boidinii grown on methanol or glucose

The complete assay system contained, in $1 \mathrm{ml}, 50 \mathrm{~mm}$-glycylglycine buffer pH $7 \cdot 6,2 \mathrm{~mm}-\mathrm{MgCl}_{2}$, $0.005^{\circ}(\mathrm{w} / \mathrm{v})$ TPP, 2 units glycerokinase, $1 \mathrm{~mm}$-ATP, $2.5 \mathrm{~mm}$-XuMP, $1 \mathrm{~mm}$-formaldehyde and cell-free extract. Incubation was at $30{ }^{\circ} \mathrm{C}$ and samples were withdrawn at intervals and assayed for formaldehyde as described in Methods. Cell-free extracts were prepared by sonication of unwashed $C$, boidinii.

\begin{tabular}{|c|c|c|c|}
\hline & \multicolumn{3}{|c|}{$\begin{array}{c}\text { Specific activity of formaldehyde } \\
\text { disappearance }(-) \text { or appearance }(+) \\
{\left[\text { nmol } \min ^{-1}(\text { mg protein })^{-1}\right]}\end{array}$} \\
\hline & \multicolumn{2}{|c|}{ Methanol-grown } & \multirow[t]{2}{*}{$\begin{array}{c}\text { Glucose- } \\
\text { grown }\end{array}$} \\
\hline & $\begin{array}{l}\text { Crude } \\
\text { extract }\end{array}$ & $\begin{array}{l}\text { Crude extract } \\
\text { passed through } \\
\text { Sephadex } \\
\text { G }-25\end{array}$ & \\
\hline $\begin{array}{l}\text { Complete } \\
\text { - Glycerukinase } \\
\text { - ATP } \\
\text { - XUMP } \\
\text { - XUMP, ATP, glycerokinase }\end{array}$ & $\begin{array}{l}-74 \\
-71 \\
-31 \\
+22 \\
+23\end{array}$ & $\begin{array}{r}-118 \\
-\quad 95 \\
-\quad 75 \\
+\quad 7 \\
-\quad 3\end{array}$ & $\begin{array}{r}-20 \\
-28 \\
-\quad 9 \\
-8 \\
\text { NT }\end{array}$ \\
\hline Complete, but with boiled extract & $<1$ & $<1$ & -7 \\
\hline
\end{tabular}

NT, Not tested.

time, DHA was established as a reaction product by colorimetric and isotopic assay following t.l.c. separation.

\section{XuMP-dependent fixation of formaldehyde}

Crude cell-free extracts of methanol-grown $C$. boidinii catalysed a reaction leading to the disappearance of formaldehyde in the presence of XuMP, $\mathrm{MgCl}_{2}$, TPP, glycerokinase and ATP (Table 1); this activity was much less in glucose-grown C. boidinii. In this assay, ATP and glycerokinase were used to pull reaction (1) from left to right by making use of the fact that the glycerokinase from Candida mycoderma catalyses the phosphorylation of not only glycerol but also DHA (Hers, 1962; Gancedo et al., 1968). Omission of glycerokinase or ATP resulted in a lowering of the rate of formaldehyde disappearance. However, when XuMP (or formaldehyde) was omitted, there was a rapid formation of formaldehyde in the assay mixture. This effect was noted on many occasions and could be as high as

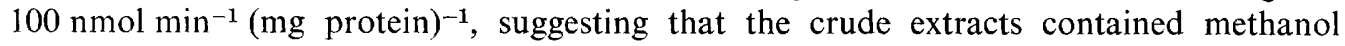
which was being oxidized to formaldehyde. This was confirmed by prior passage of the crude extract through Sephadex G-25, when much reduced rates of endogenous formaldehyde formation were observed (Table 1). However, even in such extracts it was still difficult to show unequivocally the dependence of formaldehyde fixation on the presence of XuMP and formaldehyde. Normal washing of the yeast cells prior to breakage still resulted in formaldehyde formation in the assay mixture and it was only after preincubation of harvested yeast cells in buffer for $1 \mathrm{~h}$ at room temperature that a clear and unequivocal result could be obtained (Table 2). It now became clear that methanol-grown $C$. boidinii indeed contained an enzyme system which catalysed a pentose phosphate-dependent fixation of formaldehyde, stimulated by the presence of glycerokinase and ATP. Of the three pentose phosphates tested, XuMP was the most active. There was little activity in glucose-grown cells. The specific activity of the formaldehyde fixation reaction varied in different batches of cells from 80 to $150 \mathrm{nmol} \mathrm{min}^{-1}$ (mg protein) $)^{-1}$. 
Table 2. Fixation of formaldehyde by cell-free extracts prepared from C. boidinii after preincubation in buffer

Cell-free extracts were prepared by sonication of $C$. boidinii which had been harvested and resuspended in $20 \mathrm{mM}-\mathrm{KH}_{2} \mathrm{PO}_{4} / \mathrm{NaOH}$ buffer $\mathrm{pH} 7 \cdot 1$ for $1 \mathrm{~h}$ at $18{ }^{\circ} \mathrm{C}$ prior to sonication. Formaldehyde fixation was measured in the same assay mixture and by the same method as described in Table 1.

\begin{tabular}{lcc} 
& $\begin{array}{c}\text { Specific activity of } \\
\text { formaldehyde } \\
\text { disappearance }(-)\end{array}$ \\
\multicolumn{1}{c}{ Assay system } & $\begin{array}{c}\text { Methanol- } \\
\text { grown }\end{array}$ & $\begin{array}{c}\text { Glucose- } \\
\text { grown }\end{array}$ \\
Complete & -72 & -14 \\
- XuMP, +ribulose 5-phosphate & -60 & NT \\
- XuMP, +ribose 5-phosphate & -1 & NT \\
- Glycerokinase & -58 & -11 \\
- ATP & -48 & NT \\
- XuMP & -10 & 0 \\
- TPP & -66 & NT \\
- MgCl ${ }_{2}$ & -78 & NT \\
- HCHO & -1 & NT \\
Complete, but with boiled extract & 0 & NT
\end{tabular}

NT, Not tested.

Table 3. Identification of dihydroxyacetone as a reaction product

The reaction mixture $(5 \mathrm{ml})$ was similar to that described in Table 1 , except that it lacked glycerokinase and ATP. It was incubated at $30^{\circ} \mathrm{C}$ for $15 \mathrm{~min}$ with cell-free extract of methanol-grown $C$. boidinii. The reaction was stopped by the addition of $10 \mathrm{ml}$ acetone and the acetone-soluble reaction product was analysed by t.l.c. as described in Methods. DHA was visualized by spraying with aniline phosphate.

$\begin{array}{lccr}\text { Type of plate } & \begin{array}{c}\text { Solvent } \\ \text { system }\end{array} & \begin{array}{c}\text { Dihydroxy- } \\ \text { acetone }\end{array} & \text { Reaction product } \\ \text { Cellulose } & \mathrm{A} & 0.52 & 0.52 \\ \text { Cellulose } & \mathrm{D} & 0.45 & 0.45 \\ \text { Silica gel } 60 & \mathrm{~A} & 0.61 & \text { major } 0.62 \\ & & & \text { minor } 0.49\end{array}$

\section{Identification of $\mathrm{DHA}$ as a reaction product}

Acetone-soluble reaction products were submitted to one-dimensional t.l.c. (Table 3); formation of a substance was observed which had the same $R_{F}$ as authentic DHA in three different chromatographic systems and gave a characteristic colour reaction for DHA with aniline phosphate and reduced phosphate/molybdate reagent. This reaction product was only formed in systems which contained formaldehyde, XuMP and active cell-free extract, although traces were detected in assays lacking added formaldehyde, which may be explained by the fact that crude extracts of methanol-grown cells generate significant quantities of formaldehyde (see above).

A quantitative estimate of the DHA formed in such reaction mixtures was carried out using t.l.c. and the phosphate/molybdate assay for DHA (Table 4). Results again indicated that the presence of XuMP was essential for DHA production; the DHA that was produced in the absence of added formaldehyde was due to formation of formaldehyde by crude extracts of cells which had not been preincubated in buffer prior to cell breakage. Rates of 


\section{Table 4. Rate of formation of dihydroxyacetone}

The reaction mixture $(1 \mathrm{ml})$ was similar to that described in Table 1 , except that it lacked glycerokinase and ATP. It was incubated at $30^{\circ} \mathrm{C}$ for $5 \mathrm{~min}$ with cell-free extract of methanol-grown C. boidinii. The reaction was stopped with $2 \mathrm{ml}$ acetone and the acetone-soluble product was analysed by t.l.c. on silica gel 60 with solvent system A as described in Methods. The DHA was extracted from the silica gel and estimated with phosphate/molybdate reagent.

\section{DHA formation}

[nmol $\mathrm{min}^{-1}$

Reaction mixture $\left.(\mathrm{mg} \text { protein })^{-1}\right]$

$\begin{array}{lr}\text { Complete } & 26 \cdot 5 \\ \text { - HCHO } & 19 \cdot 3 \\ \text { - XuMP } & 0 \cdot 5 \\ \text { Complete, but with boiled extract } & 0 \cdot 6\end{array}$

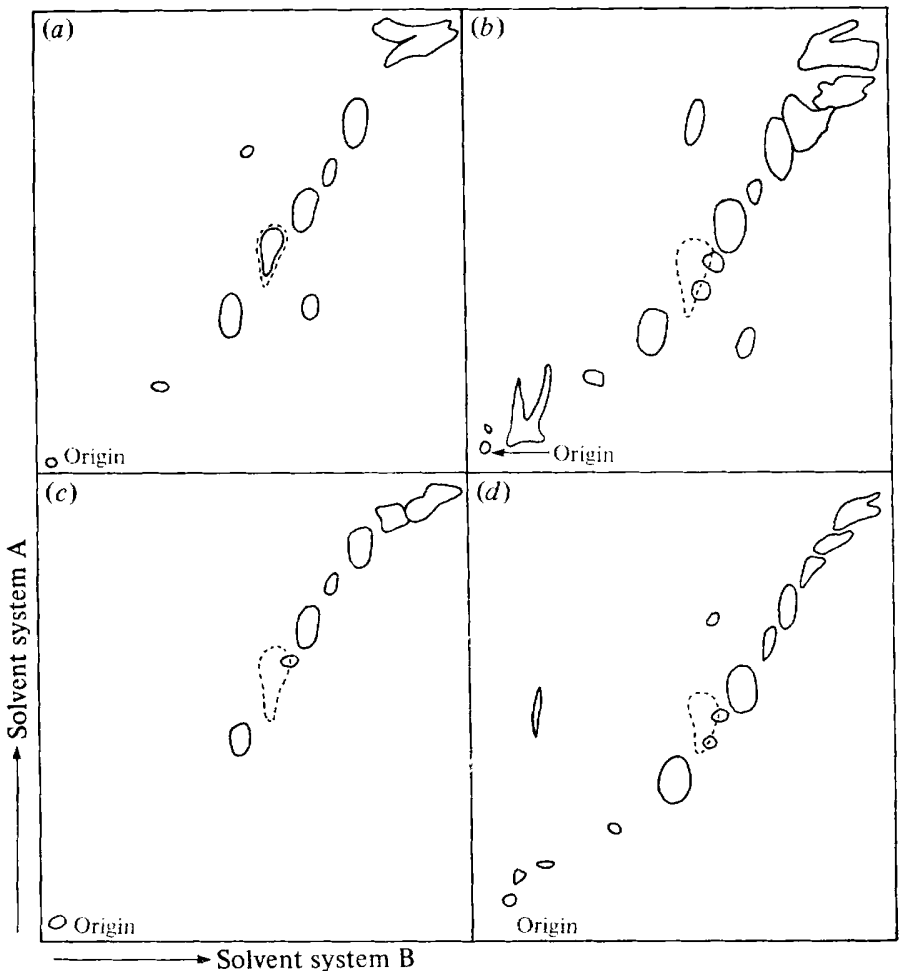

Fig. 1. T.1.c. separation and autoradiography of reaction products formed by the formaldehydefixing enzyme of cell-free extracts of $C$. boidinii. The reaction mixture $(1 \mathrm{ml})$ was similar to that described in Table 4 except that it contained $1 \mu \mathrm{mol}\left[{ }^{14} \mathrm{C}\right]$ formaldehyde $(1 \mu \mathrm{Ci}, 37 \mathrm{kBq})$ in place of unlabelled formaldehyde. It was incubated at $30^{\circ} \mathrm{C}$ for $15 \mathrm{~min}$ with cell-free extract of methanolgrown $C$. boidinii containing $200 \mu \mathrm{g}$ protein. The reaction was stopped with $2 \mathrm{ml}$ acetone and the acetone-soluble products were mixed with authentic DHA and subjected to two-dimensional t.l.c. on cellulose in solvent systems A and B as described in Methods. The t.l.c. plates were exposed to $\mathrm{X}$-ray film and the carrier DHA was visualized with aniline phosphate. (a) Complete system; $(b)$ complete system minus XuMP; $(c)$ complete system, but with boiled extract; $(d)$ complete system minus cell extract. Full lines represent radioactive spots, broken lines represent the position of carrier DHA. 
formation of DHA appeared to be somewhat lower using this assay method than the rate of formaldehyde disappearance measured in a complete assay system containing glycerokinase and ATP. This could be due to lack of displacement of the equilibrium of reaction (1) to the right or to inhibition of the reaction by DHA.

Further confirmation that DHA was a product of formaldehyde fixation was obtained using $\left[{ }^{14} \mathrm{C}\right]$ formaldehyde. A radioactive product, which was formed only by reaction systems that contained XuMP, $\left[{ }^{14} \mathrm{C}\right]$ formaldehyde and active cell-free extract, cochromatographed with authentic DHA on two-dimensional t.l.c. (Fig. 1). Despite the fact that the $\left[{ }^{14} \mathrm{C}\right]$ formaldehyde had been freshly prepared from $\left[{ }^{14} \mathrm{C}\right]$ paraformaldehyde, a considerable number of radioactive spots were visible on the t.l.c. plates even from a reaction system containing no cell extract. Such behaviour stems from the chemical reactivity of free formaldehyde. However, radioactive DHA was only formed in a complete reaction system which contained active cell-free extract.

\section{DISCUSSION}

The results of this work and that of Kato et al. (1979) establish that DHA is a product of reaction between XuMP and formaldehyde catalysed by extracts of methanol-grown C. boidinii CBS 5777 and Kloeckera sp. 2201. The simplest explanation for this is the operation of a transketolase-type reaction in which formaldehyde functions as glycolaldehyde acceptor, as in reaction (1). Coupling of reaction (1) to a triokinase:

$$
\mathrm{DHA}+\mathrm{ATP} \rightarrow \mathrm{DHAP}+\mathrm{ADP}
$$

could be expected to stimulate reaction (1) either by displacing the equilibrium from left to right or by removing DHA should it be inhibitory. Such stimulation has been observed in the present work. The coupling of reactions (1) and (2) can now offer a complete explanation of the oft-observed pentose phosphate-dependent fixation of formaldehyde catalysed by extracts of methanol-grown yeasts, and stimulated by ATP (Fuji \& Tonomura, 1974; Diel et al., 1974; Sahm, 1977; Bykovskaya \& Voronkov, 1977). This behaviour was first thought to be indicative of the presence of hexulose phosphate synthase (as in the bacterial ribulose 5-phosphate cycle) although later work showed hexulose phosphate synthase to be absent from methanol-utilizing yeasts (Kato et al., 1977; van Dijken et al., 1978). The establishment of the catalysis of reaction (1) by cell-free extracts of methanolgrown yeasts thus completes the demonstration of the presence in such cell-free extracts of all enzyme activities necessary for operation of the proposed DHA cycle (van Dijken et al., 1978; Babel \& Loffhagen, 1979; O'Connor \& Quayle, 1979). Final establishment of individual steps of the cycle, however, must await the purification of the enzyme catalysing the reaction described here. It may be noted that a specific activity for DHA synthase of $150 \mathrm{nmol} \mathrm{m^{-1 }}$ (mg protein) $)^{-1}$ would be sufficient to support a growth rate with mean generation time of $6.4 \mathrm{~h}$, assuming that the cells contain $50 \%$ of their dry weight as carbon or protein and that all the cell carbon comes via formaldehyde fixation (in practice, of course, 20 to $30 \%$ may come from carbon dioxide fixation). The figure of $6 \mathrm{~h}$ compares with a mean generation time of 6 to $8 \mathrm{~h}$ found during batch culture at $30^{\circ} \mathrm{C}$.

The detection and assay of reaction (1) in crude cell-free extracts of methanol-grown yeasts can be difficult due to interfering reactions. Measurement of the pentose phosphatedependent fixation of formaldehyde can yield non-reproducible, quite misleadingly low or even negative results due to the rapid formation of formaldehyde catalysed by some extracts. This is most probably due to a variable degree of binding of methanol within the cells, because a simple washing of cells in buffer prior to breakage is not sufficient to remove it. We have found it necessary to resuspend the cells in buffer for an hour at room temperature during which time the methanol is either slowly leached out or is oxidized by 
the methanol oxidase system. This phenomenon may account for the variable and often low specific activities of formaldehyde fixation catalysed by yeast extracts which have previously been reported in the literature.

We thank the Science Research Council for support under grant no. GR/A/65966.

\section{REFERENCES}

Babel, W. \& LoffHagen, N. (1979). Assimilation of methanol by yeasts, a new approach. Zeitschrift für allgemeine Mikrobiologie 19, 299-302.

Bykovskaya, S. V. \& Voronkov, V. V. (1977). On the properties of hexulose phosphate synthase of methylotrophic yeasts and bacteria. Mikrobiologiya 46, 36-41.

Camprell, W. R. (1926). The quantitative determination of dihydroxyacetone. Journal of Biological Chemistry 67, 59-69.

Dickens, F. \& Williamson, D. H. (1958). Formaldehyde as an acceptor aldehyde for transketolase, and the biosynthesis of triose. Nature, London $161,1790$.

Diel, F., Held, W., Schlanderer, G. \& Dellweg, H. (1974). Comparative investigations on the metabolism of formaldehyde in the presence of ribose-5-phosphate in cell free extracts of yeasts grown on methanol. FEBS Letters 38, 274-276.

FujI, T. \& Tonomura, K. (1974). Incorporation of ${ }^{14} \mathrm{C}$-formaldehyde into hexose phosphate by cellfree extracts of a methanol utilising yeast Candida sp. Agricultural and Biological Chemistry 88, 17631765.

Gancedo, C., Gancedo, J. M. \& Sols, A. (1968). Glycerol metabolism in yeasts. Pathways of utilization and production. European Journal of Biochemistry 5, 165-172.

Hers, H. G. (1962). Triokinase. Methods in Enzymology 5, 362.
Kato, N., Ohashi, H., Hori, T., Tani, Y.\& OGata, K. (1977). Properties of 3-hexulose phosphate synthase and phospho-3-hexuloisomerase of a methanol-utilizing bacterium, 77a. Agricultural and Biological Chemistry 41, 1133-1140.

Kato, N., Nishizawa, T., Sakazawa, C., Tani, Y. \& Yamada, H. (1979). Xylulose 5-phosphate dependent fixation of formaldehyde in a methanolutilizing yeast Kloeckera sp. no. 2201. Agricultural and Biological Chemistry 43, 2013-2015.

NASH, T. (1953). The colorimetric estimation of formaldehyde by means of the Hantzsch reaction. Biochemical Journal 55, 416-421.

O'Connor, M. \& QuAYle, J. R. (1979). Mutants of Hansenula polymorpha and Candida boidinii impaired in their ability to grow on methanol. Journal of General Microbiology 113, 203-208.

SAHM, H. (1977). Metabolism of methanol by yeasts. Advances in Biochemical Engineering 6, 77-103.

van Dijken, J. P., Otto, R. \& Harder, W. (1976). Growth of Hansenula polymorpha in a methanollimited chemostat. Physiological responses due to the involvement of methanol oxidase as a key enzyme in methanol metabolism. Archives of Microbiology 111, 137-144.

van Dijken, J. P., Harder, W., Beardsmore, A. J. \& QuAYLE, J. R. (1978). Dihydroxyacetone: an intermediate in the assimilation of methanol by yeasts? FEMS Microbiology Letters 4, 97-102. 